\title{
Stereoselective Synthesis of Triply-stereogenic syn,anti-Amino Diols: the Abbott Amino Diol
}

\author{
Soon Ji Kwon and Soo Y. Ko* \\ Deparment of Chemistry and Division of Holectlar Life Sciences, Ewha Womans Lniversity, Seoul 120-750, Korea \\ Recened Hav 6, 2003
}

Key Words : Abbott amino diol. Sỵnthesis. Stereoselection. Sint-amino alcohol. Anti-diol

The wide interest in amino alcohol functionality, as found in chiral auxiliaries and ligands, and in various bioactive compounds. has resulted in numerous synthetic strategies for this important class of compounds. ${ }^{1}$ Our recent contributions in this field include the preparation. from tartrate diester, of $O(1)$-benzyl-N(2)-Boc-O(3)-benzoyl-O( 4$)$-TBDMS-protected 2-anino-1.3,4-butanetriol (2). an orthogonally protected sy-2-amino-1.3,4-butanetriol. which we have proposed as a general building block for $\$ 1 n$-amino alcohol compounds. ${ }^{2}$ The proposition has been fulfilled in its use for our formal synthesis of statine. ${ }^{3}$

A glance at our statine synthesis reveals the utility of the building block 2 as well as its limitations (Scheme 1). The scheme entailed straightforward carbon-chain extensions at the C-1 and C-4 of the four-carbon unit: the amino alcohol portion of the building block was simply and passively transferred to the final product, with its stereochemistry intact. Thus. the compound 2 may be viewed as a synthetic equivalent for internal syn-anino alcohol synthon. with the orthogonally protected hydroxyl groups at the C-1 and C-4 separately conferring the electrophilicity to both the termini. necessary for regioselective $\mathrm{C}-\mathrm{C}$ bond formations (and nothing else).

While the compound 2 fulfilled its promise as a general syn-amino alcohol building block. as demonstrated in our synthesis of statine. it was envisaged that a higher oxidationstate function at either terminus would provide an opportunity for richer chemistry - a chain elongation cond functionalization. for example - and in such a case, the antino alcohol portion could assume a more active role, such as controlling the stereochenistry during the functionalization. As the $\mathrm{C}-\mathrm{I} / \mathrm{C}-4$ protected alcohol functions had been derived from the corresponding esters in the course of the preparation of the building block 2 . some of the synthetic internediates leading to the compound 2 could be employed as useful precursors for the stereoselective synthesis of more highly functionalized anino alcohol compounds, such as amino diols. The feasibility of this approach is demonstrated in our synthesis of (2S.3R.45)-2-amino-1-cyclohexyl-6-methylheptane-3.4diol, also known as the Abbott anino diol (Scheme 2). ${ }^{+}$The triply stereogenic amino diol compound is a core unit often found in renin inhibitors and is thought to be a transition state mimic of the peptide bond scission. ${ }^{5}$

One of the key steps in the preparation of the building block 2 was a chelate-controlled regioselective reduction of the ester group adjacent to the nitrogen. That yielded the hydroxyl group (the "C-1" of the compound 2). which was then benzyl-protected (5). The remaining ester function at $C(5)$ (oxazolidinone numbering) was therefore the possible site for further exploitations.

The ester group was hydrolyzed and the carbosylic acid was converted to the Weinreb's anide (6). ${ }^{6}$ Reaction of 6 with iBuMgCl yielded the desired isobutyl ketone (7). Thus, a carbon-chain extension had been achieved at one end (near the alcohol function) of the four-carbon anino alcohol portion, while at the same time. a functionality remained at that carbon so that further transformations might be possible. Upon the reduction of the carbonyl group. the amino alcohol function was then expected to exert its effect on the stereochemical outcome. In order to induce the $R e$-face attack of hydride, necessary for the generation of the $S$-configuration at $\mathrm{C}(4)$ of the Abbott amino-diol. we selected to enlist the $\alpha$ hydroxyl group for a chelate-controlled stereoselective reduction. ${ }^{7}$ Thus, the oxazolidinone ring in 7 was opened via two-step sequence of N-Bocylation followed by basic hydrolysis, so that the chelating $\alpha$-hydrosyl group was unmasked.

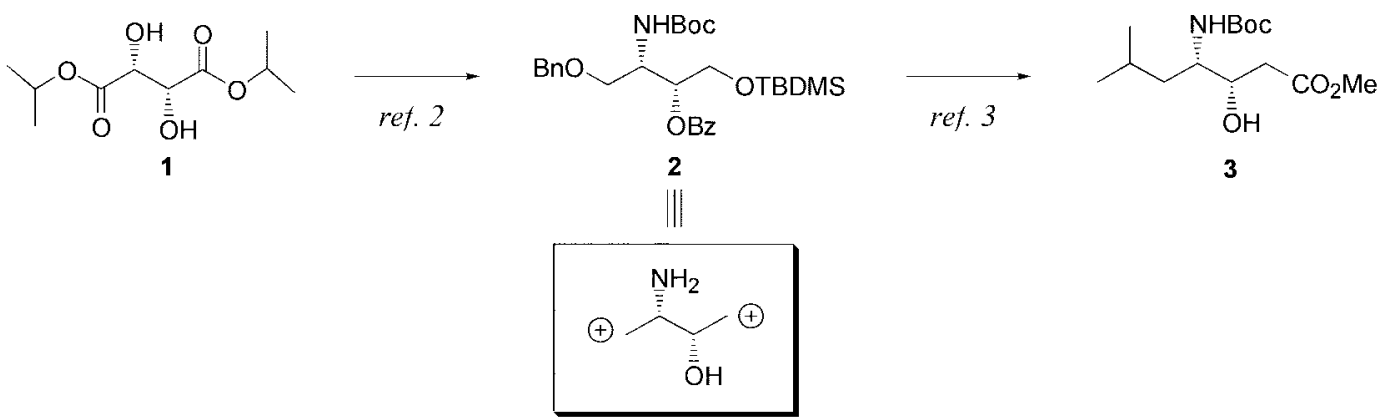

Scheme 1 
<smiles>CC(C)OC(=O)[C@@H](O)[C@@H](O)C(=O)OC(C)C</smiles><smiles>CC(C)CC(=O)[C@H](O)[C@H](COCc1ccccc1)NC(=O)OCc1ccccc1</smiles>

$\mathrm{NaB}(\mathrm{OAC})_{3} \mathrm{H}$ heCN-n-hexana (1 2:1) - 84 \% $\{$ d 585.1$\}$<smiles>CC(C)CC(O)[C@@H](O)[C@H](COC(C)(C)C)NC(=O)OCCC(=O)O</smiles><smiles>COC(=O)NC(CC1CCCCC1)[C@H](O)C(O)CC(C)C</smiles>

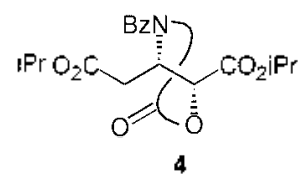

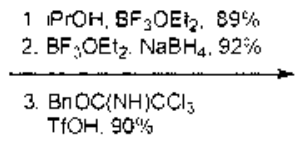
$\mathrm{THOH} .90 \%$

$\mid \begin{aligned} & 1 \mathrm{NaOH}, 98 \% \\ & 2 \mathrm{EDC}, \mathrm{OMAP}, 71 \% \\ & \mathrm{CH}_{3} \mathrm{ONHCH}_{3}\end{aligned}$

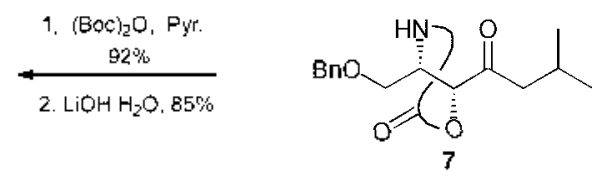<smiles>CC(C)C(C)C(C)C(C)(F)F</smiles><smiles>CON(C)C(=O)C12CN[C@@](COc3ccccc3)(C(=O)O1)C2=O</smiles><smiles>CNCC1(COCc2ccccc2)C(=O)OC1OC(C)C</smiles>

5

$$
\mathrm{N} \mathrm{O}
$$

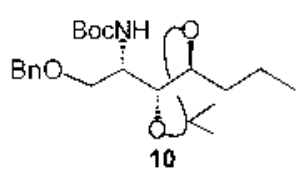

1. $\mathrm{Pd} / \mathrm{C} \mathrm{H}_{2}, 99 \%$
2. $\mathrm{MsCl} . \mathrm{El}_{2} \mathrm{~N}, 87 \%$
3. $\mathrm{NaH}, 83 \%$

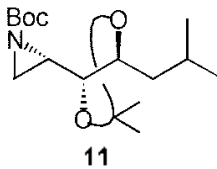

11

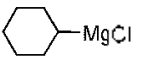

$\mathrm{CuBr} \mathrm{SMe}_{2} 89 \%$<smiles>C1CC2(C1)CC2</smiles>

12

Scheme 2

The reduction of the carbonyl group in 8 with $\mathrm{Na}(\mathrm{OAc})_{3} \mathrm{BH}$ in MeCN-n-hexane $(1.2 ; 1)$ gave the best results, producing the desired (4S)-isomer (9) in 8.5: 1 diastereoselectivity and $84 \%$ contbined yield. ${ }^{8}$ The diastereomers were cleanly separated on a silica column.

The remaining transformations leading to the final product were now straightforward. The $a n t i$-diol (9) was protected. and the cyclohexyl group was introduced following the reaction sequence already explored for the statine synthesis. ${ }^{3}$ Thus. the unntasking of the $\mathrm{C}(1)$-hydrosyl group was followed by activation as the mesylate. It was converted to the N-Boc-aziridine (11). which was then ring-opened using a cyclohexyl Grignard reagent in the presence of $\mathrm{CuBr}$ catalyst (12). Finally. a mildly acidic hyddrolỵsis resulted in the acetonide deprotection. leaving the N-Boc group intact. to give the N-Boc-protected Abbott amino-diol (13).

The present synthesis described herein shows a useful extension of the synthetic strategy, originally developed for doubly-stereogenic $\$ 7 n$-amino alcohol compounds to be applied for the synthesis of triply-stereogenic stn, anti-amino diols.

Acknowledgment. This work was supported by the KRF (2000-015-DP027I). S.J.K. is grateful to the Brain Korea 21 project for a graduate fellowship.

\section{References and Footnotes}

1. (a) Ager. D. J.: Prakash. I.: Schaad. D. R. Them. Res. 1996.96, 835. (b) Cardillo. G.: Tomasini. C. Chent. Soc. Rev 1996. 25. 117. (c) Juaristi. E. Entmioselective Sinthesis of B-Amino Acids: Wiley-VCH: New York. 1997. (d) Juraristi. E.: Quintana. D.: Escalante. I. Aldrchm. Acta 1994 27, 3. (e) Cole. D. C. Tetrahedron $1994,50,9517$.

2. Kwon, S. J: Ko. S. Y. J. Org Chem 2001, 66. 6833.
3. Kwon. S. J.; Ko, S. Y. Tetrahedron Lett. 2002, +3.639

4. Recent syntheses: (a) Chandraselhar. S.: Mohapatra. S.: Yadaq. J. S. Tetrahedron 1999. 55. 4763. (b) Beaulieu. P. L.: Gillard. T.: Bailey. M.: Beaulieu. C.: Duceppe. T. S.: Lavallee. P.: Wernic. D. J. Org. Chem. 1999. 64. 6622. (c) Schwindt, M. A.: Belmont. D. T.: Carlson, M: Franklin, L. C.: Hendrickson, V. S.: Karrick, G. L: Poe. R. W. Sobieray, D. M; Vusse, J. V. D. J. Org Chent. 1996. 61. 9564. (d) Alesander. C. W. Liotta. D. C. Tetrahedon Lett. 1996. 37. 1961. (e) Spero. D. M.: Kapadia. S.: Farina. V. Tetrahedron Lett. 1995. 36. 4543, (f) Krysan. D. T.: Haight. A. R.: Menzia, J. A.; Welch. N. Tetrahedron 1994, 50, 6163. (g) Krysan. D. J.; Rockway. T. W. Haight. A. R. Tetahedron: Aswmmeny 1994. 5. 625. (h) Chan, M. F.: Hsiao, C. N. Tetrahedhon Leth. 1992. 33.3567 .

5. (a) Thaisrivongs. S.: Turner. S. R.: Strohbach. I. W.: Terbrinks. R. E.: Tarpley. W. G.: Mequade. T. T.: Heinrikson. R. L.: Tomasselli. A. G.: Hui. J. O.; Jeffreyhowe. W. J. Med. Chem 1993. 36. 941. (b) Patt. W. C.: Hamilton, H. W.; Taylor, M. D; Rayn. M. J.; Taylor, D. G.; Connolly. C. J. C.: Doherty, A. M.: Klutchko, S. R.: Sircar. I.: Steinbaugh. B. A.: Batley. B. L.: Painchaud. C. A.: Rapundalo. S. T.: Michniewicz. B. M.: Olson. S. C.J. Hed Chent. 1992. 35. 2562. (c) Luly. T. R.: Bamaung. N.: Soderquist. T.: Fung. A. K. L.; Stein, H: Kleinert. H. D: Marcotte. P. A.; Egan. D. A.: Bopp. B.: Merits. I.; Boils, G.; Greer, J; Perun. T. J. Hed. Chem. 1988. 31. 2264. (d) Kleinert. H. D.: Rosenberg. S. H. Baker. W. R.: Stein. H. H.: Klinghofer. V: Barlow. T.: Spina. K.: Polakowski. J.: Kovar. P.: Cohen. J: Denissen. T. Science 1992. 257. 1940.

6. (a) Nahm. S.: Weinreb. S. M. Tetohedron Lett. 1981. 22. 3815 (b) Clark. D. L.: Heathcock. C. H. J. Org. Chem. 1993. 58,5878 .

7. Review: Mengel. A.: Reiser. O. Chem Rev: 1999, 99, 1191.

8. (a) The reaction conditions were adopted from a literature precedent. See ref. 4 (c). (b) The configuration of the $C(4)$ center was assigned to be $(S)$ based on literature precedents: the subsequent reactions yielded the compounds already reported in the literature. which confirmed the initial stereochemical assignment to be correct.

9. All the synthetic compounds described in the paper exhibit satisfactory spectroscopic and elemental analytical data. 